\title{
INTERSTITIAL DELETION OF THE LONG ARM OF CHROMOSOME 2: A CASE REPORT AND REVIEW OF THE LITERATURE
}

\author{
Yukio Takahashi, Kouji Narahara, Kiyoshi Kikkawa, Yoshiharu Wakita, \\ Shunsuke Kimura, ${ }^{1}$ Masae MuraKami, Ryozo KasaI, ${ }^{2}$ and Hiroshi Kimoto ${ }^{1}$ \\ ${ }^{1}$ Department of Pediatrics, Okayama University School of Medicine, \\ Okayama 700, Japan \\ ${ }^{2}$ Asahigawa Jidoin Hospital for Handicapped Children, \\ Okayama 703, Japan
}

\begin{abstract}
Summary A girl with mental retardation and multiple anomalies was shown to have a de novo interstitial deletion of the long arm of chromosome $2(2 \mathrm{q} 23.3 \rightarrow \mathrm{q} 24.2)$ by the use of high resolution banding technique. Review of the literature revealed that her clinical features resembled those of the previously reported cases with monosomy for the middle portion of $2 \mathrm{q}$.
\end{abstract}

\section{INTRODUCTION}

Partial monosomy $2 \mathrm{q}$ is a rare chromosome aberration, and only 14 cases have been reported. The vast majority of them had an interstitial deletion of $2 q$. The recent technical advances leading to the improvement of banding resolution have facilitated the detection of subtle chromosome rearrangements. In this paper, we describe an additional case with a deletion of the short segment of the middle portion of $2 q$, which has been identified first by the high resolution banding technique. The published cases with a deletion of the long arm of chromosome 2 were reviewed.

\section{CASE REPORT}

The patient, an 8-year-old girl, was born to a 25 -year-old mother and a 27 -yearold father. They were unrelated and healthy. Her birth weight was $2,400 \mathrm{~g}$. She had been cared for in an incubator during the first month of life. At that time, chromosome constitution was reported to be normal. Her psychomotor development was severely retarded: head control at 1 year and sitting without support at 3 years. Generalized tonic clonic convulsions had been noticed since 5 years and 2 months of age. At the age of $61 / 2$ years, the body weight was $12.0 \mathrm{~kg}$, length 95.0 $\mathrm{cm}$ and head circumference $44.0 \mathrm{~cm}$ (all far below the third percentile). She was found to have microcephaly with frontal bossing, thick eyebrows, antimongoloid

Received June 20, 1985; revised version received October 13, 1985 


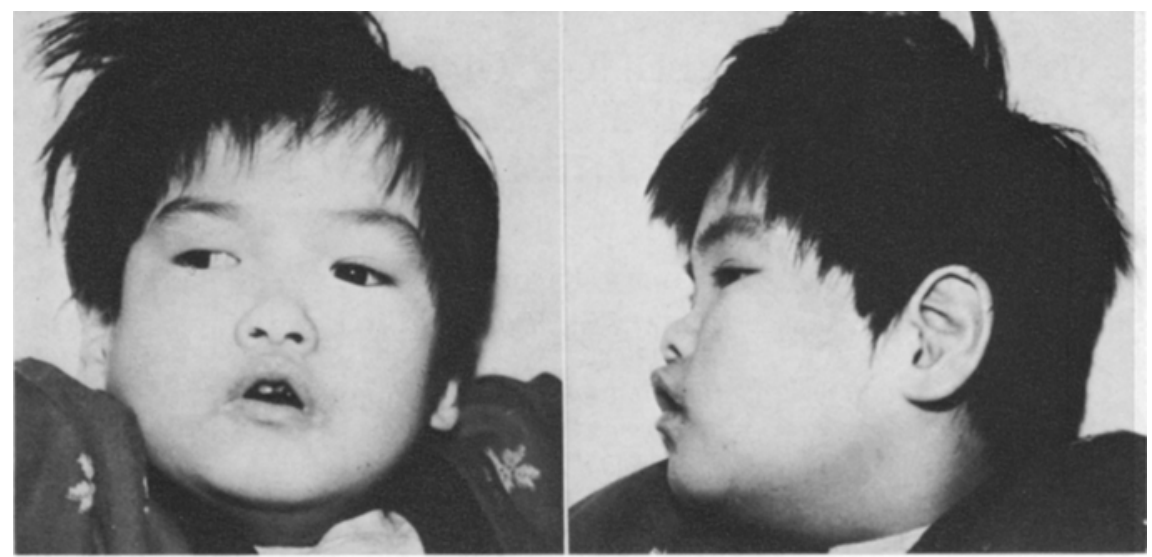

A

B

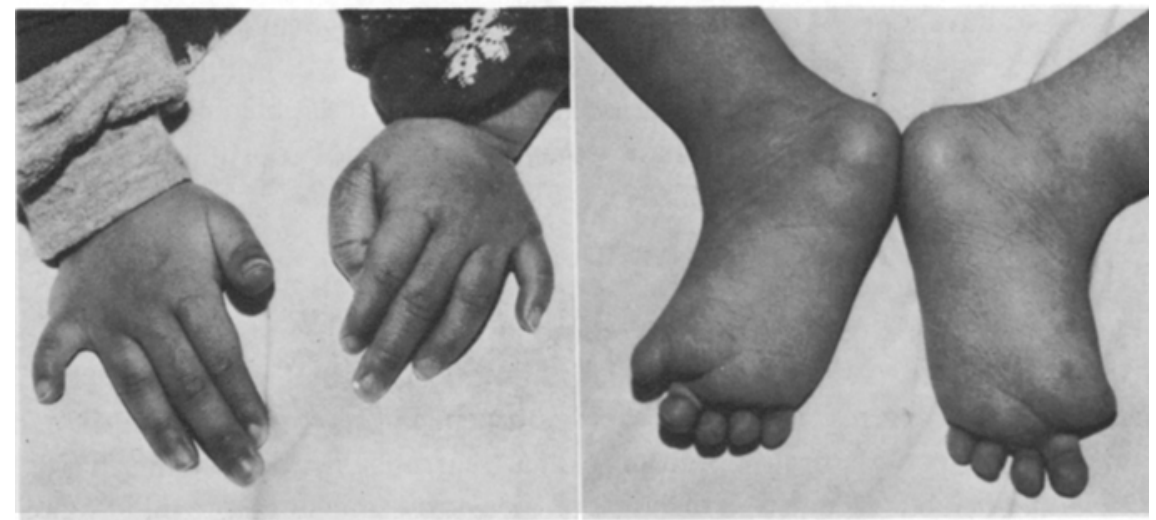

C

D

Fig. 1. Present case.

palpebral fissures, left ptosis, external strabismus, congenital cataract, low-set ears, small nose with anteverted nostrils and flat nasal root, small mouth with bow-shaped upper lip, mild micrognathia, irregular dental arches and high-arched palate (Fig. 1, A and B). Hypertrichosis was noted over the forehead and the back. Thumbs were implanted proximally, and both fifth fingers were short (Fig. 1C). The first toes were bilaterally absent, the second toes were tibially incurved, and a large cleft between the first and second toes was seen on the right foot (Fig. 1D). Although no heart murmurs were audible, grade I A-V block was disclosed on electrocardiogram. Radiological examinations demonstrated open foramen parietalis, lumbar scoliosis, flat femoral head, hypoplasia of the middle and distal phalanges of the fifth fingers and absence of the proximal phalanges of the first toes (Fig. 2, A to D). 


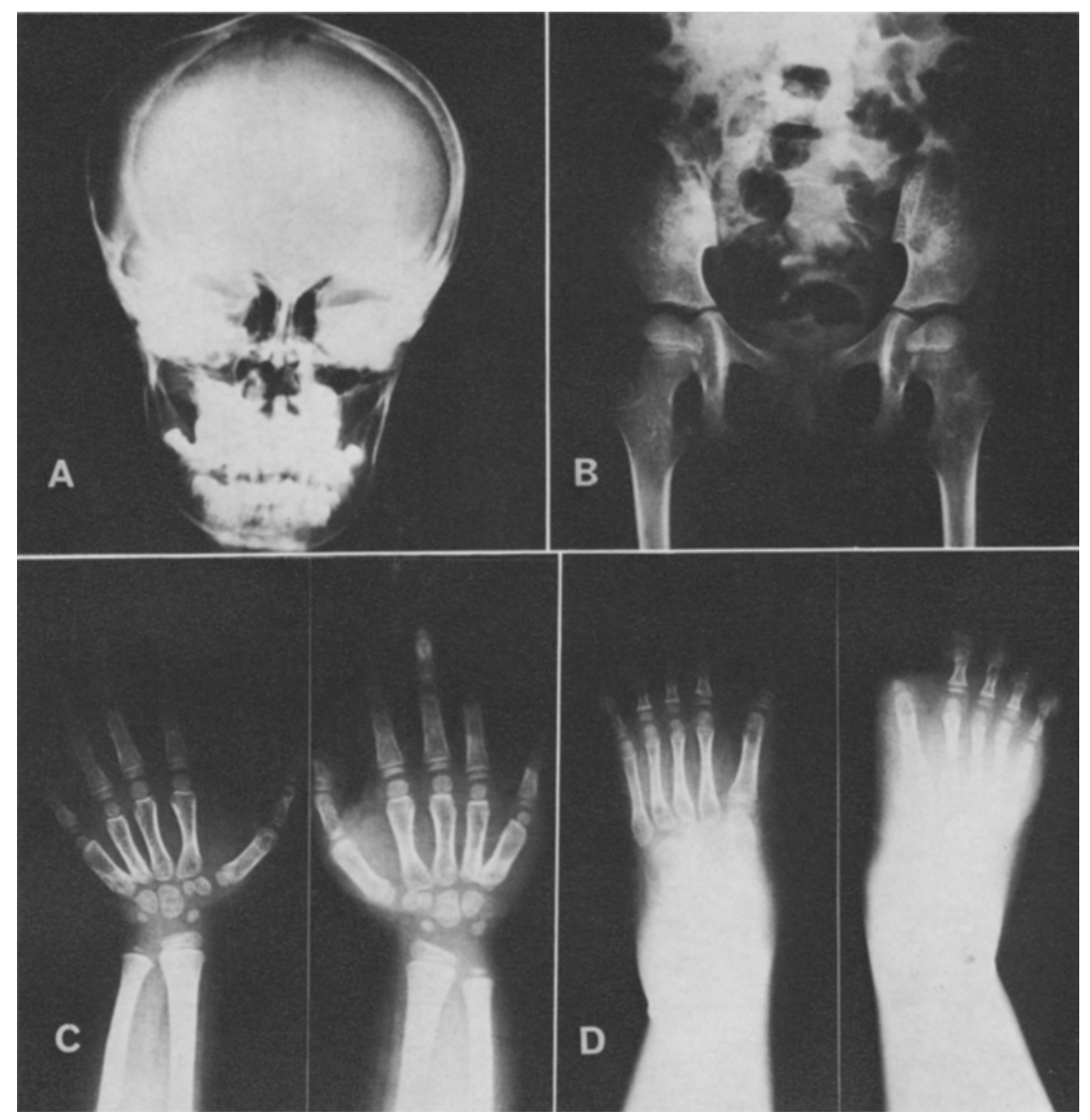

Fig. 2. Roentgenograms of the skull (A), spine and pelvis (B), hands (C) and feet (D).

\section{Dermatoglyphic findings}

Digital patterns were $L^{r} . L^{u} \cdot L^{u} . L^{u} . L^{u}$ on the right hand and $W, L^{u} . L^{u} . L^{u}, W$ on the left (Fig. 3). A total finger ridge count was 114. The right and left hand

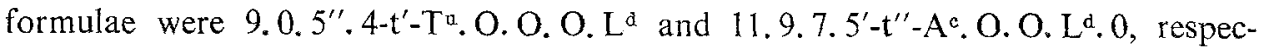
tively (Fig. 3). There were supernumeraly flexion creases on both thumbs and single flexion creases on both fifth fingers.

\section{Cytogenetic findings}

Cells in prometaphase and prophase were obtained from peripheral blood lymphocytes cultures, using the method of Ikeuchi and Sasaki (1979). High resolution banding analysis showed an interstitial deletion of the long arm of chromosome 

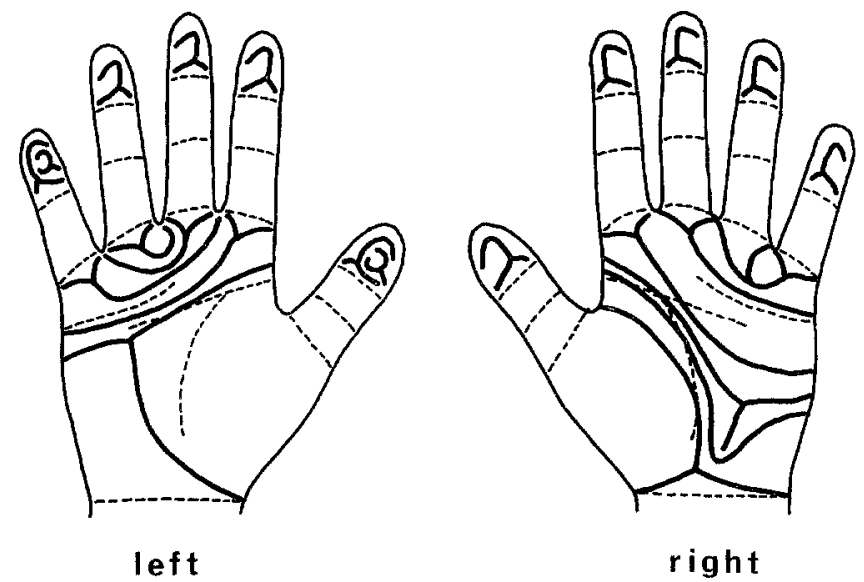

Fig. 3. Dermatoglyphics of the case.

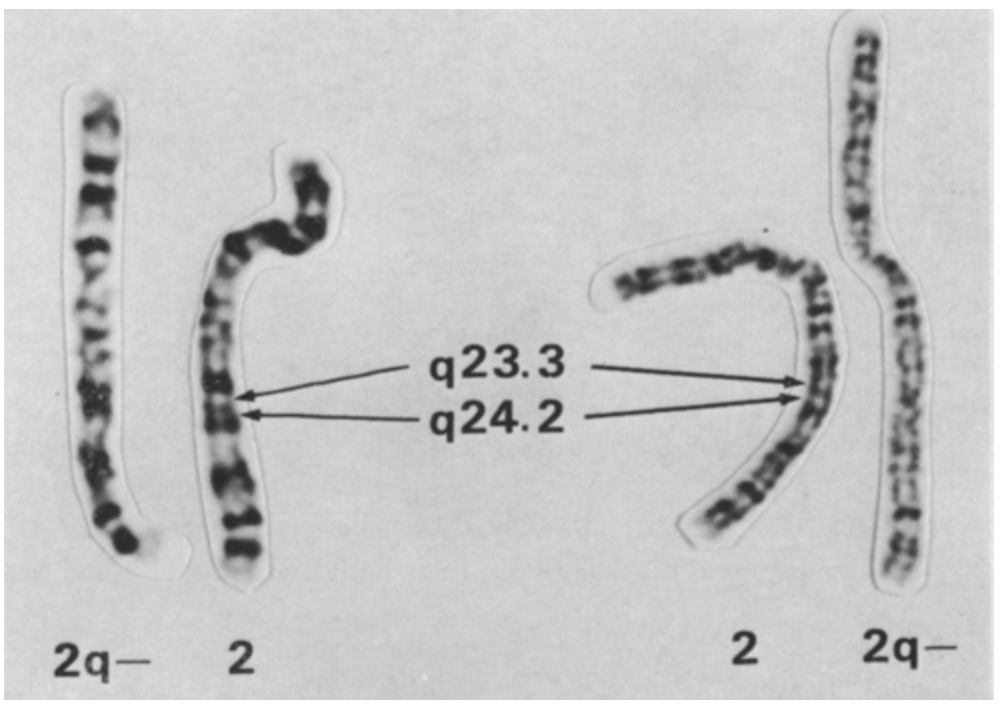

Fig. 4. Partial G-banded karyotypes. Arrows indicate breakpoints.

2 in all cells examined (Fig. 4). The karyotype was 46,XX,del (2) (pter $\rightarrow$ q23.3: : $\mathrm{q} 24.2 \rightarrow \mathrm{qter})$. Both parents had normal karyotypes.

\section{Gene dosage studies}

Red cell ACP, MDH and IDH activities were assayed according to the methods of Hopkinson et al. (1964), Bergmeyer and Bernt (1974), and Narahara et al. (1985), respectively. $A C P_{1}$ isozymes were separated on a starch gel as described by Harris 
and Hopkinson (1976). In our case, the $\mathrm{ACP}_{1}$ phenotype was $\mathrm{BA}$, and the $\mathrm{ACP}_{1}$ activity was normal $(145.1 \mathrm{U} / \mathrm{gHb}$; normal values of type $\mathrm{BA}(\mathrm{n}=67), 157.3 \pm 15.9$ $\mathrm{U} / \mathrm{gHb})$. The $\mathrm{MDH}_{1}$ and $\mathrm{IDH}_{1}$ activities were also normal $\left(\mathrm{MDH}_{1}, 81.6 \mathrm{U} / \mathrm{gHb}\right.$; normal $(\mathrm{n}=20), 82.1 \pm 12.5 \mathrm{U} / \mathrm{gHb} ; \mathrm{IDH}_{1}, 0.479 \mu \mathrm{mol} / \mathrm{min} / \mathrm{gHb}$; normal $(\mathrm{n}=100)$, $0.505 \pm 0.103 \mu \mathrm{mol} / \mathrm{min} / \mathrm{gHb}$ ). The normal $\mathrm{IDH}_{1}$ activity in our case excluded the $\mathrm{IDH}_{1}$ locus from the region $2 \mathrm{q} 23.3 \rightarrow \mathrm{q} 24.2$.

\section{DISCUSSION}

The published cases with partial monosomy $2 \mathrm{q}$ including ours differ considerably in deleted segments (Fig. 5) as well as in clinical features (Table 1). On the cytological basis, these cases can be classified into four groups: group 1 represents monosomy for the $2 q 1$ band (case 2), group 2 monosomy for the $2 q 2$ band (cases 1, 3, 4 and 6), group 3 monosomy for the proximal $2 \mathrm{q} 3$ band (cases 7, 8, 9, 10 and 11) and group 4 monosomy for the distal $2 \mathrm{q} 3$ band (cases 12,13,14 and 15). Case 5, in which a deletion involved the $2 \mathrm{q} 2$ and proximal $2 \mathrm{q} 3$ bands, is classifiable into both groups 2 and 3. Phenotypic delineation of group 1 is impossible, because no detailed clinical description of the case was given. Two cases with a terminal deletion in group 4 (cases 14 and 15) had some distinctive features such as acrocephaly and syndactyly, suggesting that the terminal deletion of $2 q 37$ may be established as a clinical entity in future.

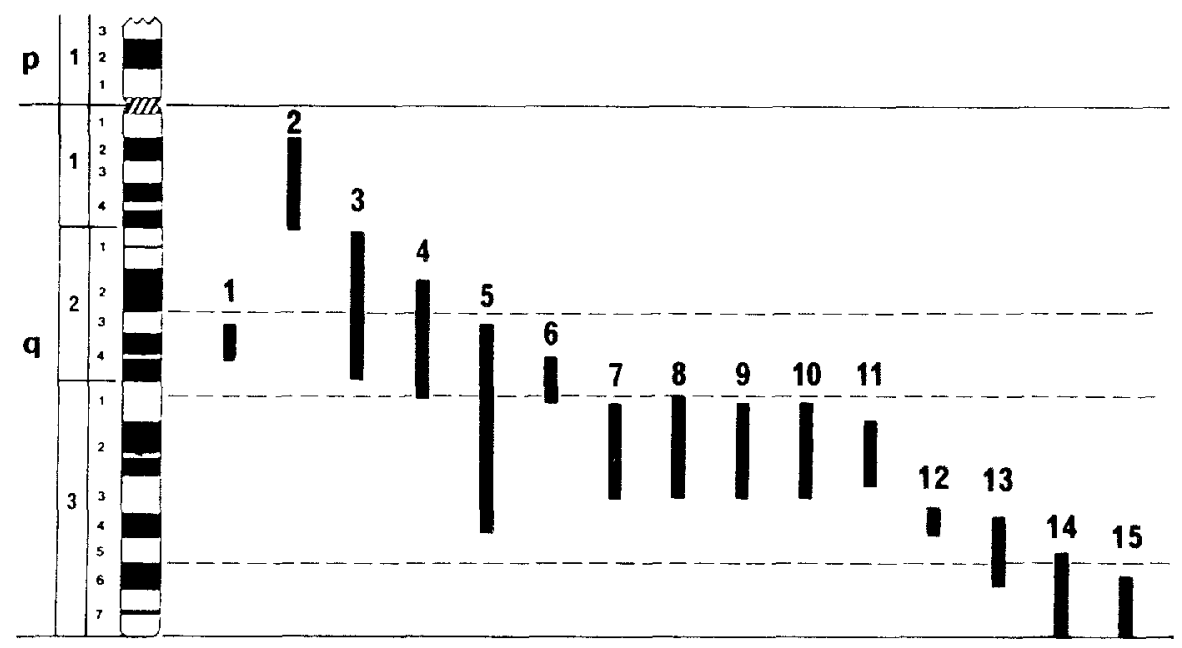

Fig. 5. Schematic representation depicting the segments deleted in the reported cases with partial monosomy 2q. 1: present case; 2: Antich et al. (1981); 3: Fryns et al. (1977); 4: McConnell et al. (1980); 5: Shabtai et al. (1982); 6: Moller et al. (1984); 7: Franceshini et al. (1983); 8: Buchanan et al. (1983); 9: Taysi et al. (1981); 10: Young et al. (1983); 11: Pai et al. (1983); 12: Narahara et al. (1985); 13: Warter et al. (1976); 14: Sanchez and Pantano (1984); and 15: Young et al. (1983). 
Table 1. Clinical findings of the reported

\begin{tabular}{|c|c|c|c|c|c|c|}
\hline Case No. ${ }^{a}$ & 1 & 2 & 3 & 4 & 5 & 6 \\
\hline Deleted segment & $\begin{array}{l}\mathrm{q} 23.3- \\
\mathrm{q} 24.2\end{array}$ & $q 12-q 14$ & $\mathrm{q} 21-\mathrm{q} 24$ & $\mathrm{q} 22-\mathrm{q} 31$ & $q 23-q 24$ & $\begin{array}{r}\mathrm{q} 24.2- \\
\mathrm{q} 3105\end{array}$ \\
\hline Sex & $\mathrm{F}$ & M & $\mathrm{F}$ & $\mathrm{F}$ & $F$ & $F$ \\
\hline Age at diagnosis & $6 y$ & Newborn & Newborn & Newborn & $20 y$ & $4 y$ \\
\hline Birth weight & $2,400 \mathrm{~g}$ & ND & $2,500 \mathrm{~g}$ & $1,500 \mathrm{~g}$ & $2,930 \mathrm{~g}$ & ND \\
\hline Mental retardation & + & ND & + & + & + & + \\
\hline Growth failure & + & $?$ & ? & $?$ & + & + \\
\hline Microcephaly & + & $\mathrm{ND}$ & - & Meningo- & - & + \\
\hline Macrocephaly & - & ND & + & myelocele & - & - \\
\hline Low-set/or malformed ears & $+1-$ & $+1+$ & $\mathrm{NDb}$ & $+1+$ & $+1+$ & $+/+$ \\
\hline Microphthalmia & - & ND & + & ND & + & - \\
\hline Ptosis & + & ND & + & + & + & - \\
\hline Cataract & + & ND & + & ND & + & - \\
\hline Corneal opacity & - & ND & + & ND & ND & - \\
\hline Antimongoloid slanting of the eyes & + & ND & ND & ND & + & + \\
\hline Frontal bossing & + & + & + & + & ND & ND \\
\hline Small upturned nose & + & $\mathrm{ND}$ & + & ND & + & + \\
\hline Prominent nose & - & ND & - & ND & - & - \\
\hline Cleft lip/or palate & high-arched & + & + & + & + & - \\
\hline Microstomia & + & ND & + & ND & ND & ND \\
\hline Macrostomia & - & ND & - & ND & ND & ND \\
\hline Micrognathia & - & + & + & + & ND & - \\
\hline Defective dentition & + & $?$ & $?$ & $?$ & + & ND \\
\hline Short neck & - & + & + & ND & ND & ND \\
\hline Scoliosis & + & ND & ND & + & + & + \\
\hline Cardiac defects & - & Murmur(+) & PDA & PTA $^{c}$ & Murmur $(+)$ & ND \\
\hline Hypoplastic nipples & - & ND & $\mathrm{ND}$ & + & + & ND \\
\hline Flexion deformity of the fingers & - & + & + & + & + & + \\
\hline Arachnodactyly & - & ND & + & $\mathrm{ND}$ & + & + \\
\hline $\begin{array}{l}\text { Large cleft between the } 1 \text { st and } \\
\text { 2nd toes }\end{array}$ & - & ND & + & + & + & + \\
\hline Prominent calcanei & - & ND & ND & + & + & ND \\
\hline Pes equinovarus & - & ND & ND & ND & ND & ND \\
\hline Syndactyly of the fingers or toes & - & ND & - & - & - & - \\
\hline
\end{tabular}

${ }^{a}$ The same numbers as in Fig. $4,{ }^{b}$ not described, ${ }^{c}$ persistent truncus arteriosus, d coarctation of the aorta.

Jpn. J. Human Genet. 
cases with a interstitial deletion of $2 \mathrm{q}$.

\begin{tabular}{|c|c|c|c|c|c|c|c|c|}
\hline 7 & 8 & 9 & 10 & 11 & 12 & 13 & 14 & 15 \\
\hline $\mathrm{q} 31-\mathrm{q} 33$ & q31-q33 & $q 31-q 33$ & $q 31-q 33$ & $q 32(q 31-q 33)$ & $q 33.3-q 35$ & $q 34-q 36$ & q35-quer & q36-qter \\
\hline $\mathrm{F}$ & $\mathrm{F}$ & $F$ & $\mathrm{M}$ & $\mathbf{F}$ & $\mathrm{F}$ & $F$ & $\mathrm{~F}$ & $\mathrm{~F}$ \\
\hline $11 \mathrm{y}$ & Newborn & $7 y$ & $4 \mathrm{~m}$ & $3 y$ & $4 y$ & $6 y$ & Newborn & $8 \mathrm{~m}$ \\
\hline ND & $2,300 \mathrm{~g}$ & $2,700 \mathrm{~g}$ & $2,580 \mathrm{~g}$ & $2,060 \mathrm{~g}$ & $3,000 \mathrm{~g}$ & $2,800 \mathrm{~g}$ & $2,100 \mathrm{~g}$ & $2,300 \mathrm{~g}$ \\
\hline+ & + & + & + & $t$ & + & - & + & + \\
\hline+ & $?$ & + & + & + & - & + & $?$ & + \\
\hline $\mathrm{ND}$ & + & + & ND & + & - & + & + & + \\
\hline $\mathrm{ND}$ & - & - & ND & - & - & - & - & - \\
\hline ND & $\mathrm{ND} /+$ & $+/ t$ & $+1+$ & $\mathrm{ND} /-$ & - & $+/+$ & $+/ t$ & $+/+$ \\
\hline+ & + & - & + & ND & - & - & - & - \\
\hline+ & + & + & + & ND & - & - & - & - \\
\hline- & - & - & - & ND & - & - & - & - \\
\hline ND & + & ND & $\div$ & ND & - & - & - & - \\
\hline+ & ND & ND & ND & ND & - & - & + & + \\
\hline ND & + & + & $\mathrm{ND}$ & + & - & ND & - & - \\
\hline- & - & - & - & + & - & + & + & + \\
\hline+ & + & + & + & - & - & - & - & - \\
\hline+ & + & ND & ND & ND & - & - & high-arched & + \\
\hline ND & + & ND & ND & - & - & - & - & ND \\
\hline ND & - & $\mathrm{ND}$ & ND & + & - & + & + & ND \\
\hline+ & + & ND & + & + & - & ND & + & ND \\
\hline $\mathrm{ND}$ & $?$ & ND & $?$ & ND & - & + & $?$ & ND \\
\hline ND & ND & ND & ND & + & - & - & ND & ND \\
\hline ND & ND & ND & ND & $\mathrm{ND}$ & - & - & ND & ND \\
\hline ND & $\begin{array}{l}\mathrm{CoA} d \\
\quad+\mathrm{ASD}\end{array}$ & $\mathrm{PS}+\mathrm{PDA}$ & - & ND & - & $\mathrm{ASD}$ & ND & ND \\
\hline $\mathrm{ND}$ & ND & $\mathrm{ND}$ & ND & ND & - & ND & ND & inverted \\
\hline+ & + & + & ND & + & - & - & $\mathrm{ND}$ & ND \\
\hline ND & + & ND & ND & Brachydactyly & - & - & ND & + \\
\hline ND & + & + & ND & + & - & ND & ND & ND \\
\hline ND & $\mathrm{ND}$ & ND & ND & $\mathrm{ND}$ & - & ND & ND & ND \\
\hline $\mathrm{ND}$ & + & ND & + & + & - & - & ND & ND \\
\hline+ & - & - & $T$ & - & - & - & + & + \\
\hline
\end{tabular}


Intriguingly, phenotypes of ten cases in groups 2 and 3 resembled each other. Clinical features shared by the majority of them included mental retardation, growth failure, microcephaly, low-set ears, ptosis, antimongoloid slanting of eyes, frontal bossing, micrognathia, cleft palate, cardiac defect, flexion deformity of fingers, arachnodactyly and large cleft between the first and second toes. On the other hand, cataract, small upturned nose, microstomia, scoliosis and prominent calcanei were more frequently observed in group 2, while microphthalmia, prominent nose, macrostomia, syndactyly and pes equinovarus were more frequently seen in group 3 . The fact that all cases in the two groups had large cleft between the first and second toes in common indicates that a deletion of the segment $2 \mathrm{q} 24.2 \rightarrow \mathrm{q} 31$ may be related to this abnormality.

The phenotypic similarity between groups 2 and 3 in spite of the differences in the location and extent of deletions involved is difficult to explain. It may result either from the misinterpretations of the breakpoints in some cases in group 3 or from the existence of similar genetic materials both in the distal $2 \mathrm{q} 2$ and in the proximal $2 \mathrm{q} 3$ regions. The recent gene mapping data, however, make the latter explanation unlikely (HGM 7, 1983).

It should be noted that many clinical features seen in cases with monosomy for the middle portion of $2 q(2 q 2$ and proximal $2 q 3)$ are nonspecific. Further case reports are required to establish whether this chromosome abnormality constitutes a clinically recognizable syndrome.

\section{REFERENCES}

Antich, J., Carbonell, X., and Clusellas, N. 1981. De novo interstitial deletion of the long arm of chromosome 2 in a malformed newborn-karyotype: 46,XY,del(2) (q12q14). Clin. Genet. 19: 489.

Bergmeyer, H.U. and Bernt, E. 1974. Methods of Enzymatic Analysis, 2nd Ed., Academic Press, New York, pp. 613-617.

Buchanan, P.D., Rhodes, R.L., and Stevenson, C.E., Jr. 1983. Interstitial deletion 2q31-q33. Am. J. Med. Genet. 15: 121-126.

Franceschini, P., Cirillo Silengo, M., Davi, G., Biano, R., and Biagioli, M. 1983. Interstitial deletion of the long arm of chromosome $2(\mathrm{q} 31 \mathrm{q} 33)$ in a girl with multiple anomalies and mental retardation. Hum. Genet. 64: 98.

Fryns, J.P., Van Bosstraeten, B., Malbrain, H., and Van den Berghe. 1977. Interstitial deletion of the long arm of chromosome 2 in a polymalformed newborn-karyotype : 46,XX, del(2) (q21; q24). Hum. Genet. 39:233-238.

Harris, H. and Hopkinson, D.A. 1976. Handbook of Enzyme Electrophoresis in Human Genetics, North Holland Publishing Company, Amsterdam.

Hopkinson, D.A., Spencer, N., and Harris, H. 1964. Genetical studies on human red cell acid phosphatase. Am. J. Hum. Genet. 16: 14l-154.

Human Gene Mapping 7, 1983, Los Angeles Conference. 1984. Cytogenet. Cell Genet. 37: 1-666.

Ikeuchi, T. and Sasaki, M. 1979. Accumulation of early mitotic cells in ethidium bromide-treated human lymphocytes cultures. Proc. Jpn. Acad. 55: 15-18.

McConnell, T.S., Kornfeld, M., McClellan, G., and Aase, J. 1980. Partial deletion of chromosome 2 mimicking a phenotype of trisomy 18: case report with autopsy. Hum. Pathol. 11: 202-205. 
Moller, M., Garcia-Cruz, D., Rivera, H., Sanchez-Corona, J., and Cnatu, J.M. 1984. Pure monosomy and trisomy $2 \mathrm{q} 24.2-\mathrm{q} 3105$ due to an inv ins $(7 ; 2)(\mathrm{q} 21.2 ; \mathrm{q} 3105)$ segregating in four generations. Hum. Genet. 68: 77-86.

Narahara, K., Kimura, S., Kikkawa, K., Takahashi, Y., Wakita, Y., Kasai, R., Nagai, S., Nishibayashi, Y., and Kimoto, H. 1985. Probable assignment of soluble isocitrate dehydrogenase $\left(\mathrm{IDH}_{1}\right)$ to $2 \mathrm{q} 33.3$. Hum. Genet., 71: 37-40.

Pai, G.S., Rogers, J.F., and Sommer, A. 1983. Identical multiple congenital anomalies/mental retardation (MCA/MR) syndrome due to del(2) (q32) in two sisters with intrachromosomal insertional translocation in their father. Am. J. Med. Genet. 14: 189-195.

Sanchez, J.M. and Pantano, A.M. 1984. A case of deletion $2 q 35 \rightarrow$ qter and a peculiar phenotype. J. Med. Genet. 21 : 147-149.

Shabtai, F., Klar, D., and Halbrecht, I. 1982. Partial monosomy of chromosome 2. Delineable syndrome of deletion 2 (q23-q31). Ann. Genet, (Paris). 25: 156-158.

Taysi, K., Dengler, D.R., Jones, L.A., and Heersma, J.R. 1981. Interstitial deletion of the long arm of chromosome 2. Ann. Genet. (Paris), 24: 245-247.

Warter, S., Lausecker, C., and Pennerath, A. 1976. Etude chromosomique et clinique d'une fillette porteuse d'une deletion (2) (q34q36). Hum. Genet. 32: 225-227.

Young, R.S., Shapiro, S.D., Hansen, K.L., Hine, L.K., Rainosek, D.E., and Guerra, F.A. 1983. Deletion $2 \mathrm{q}$ : two new cases with karyotypes $46, X Y$,del(2) (q31q33) and 46,XX,del(2) (q36). J. Med. Genet. 20: 199-202. 